\title{
Determinants of Competitive Advantages of Dates Exporting: An Applied Study on Saudi Arabia
}

\author{
Gaber Mohamed M. Abdel Gawad ${ }^{1}$, Tarek Tawfik Alkhteeb ${ }^{1,2} \&$ Mohammad Tariq Intezar $^{1}$ \\ ${ }^{1}$ College of Business Administration, Salman Bin Abdulaziz University, Kingdom of Saudi Arabia \\ ${ }^{2}$ Agricultural Economics Department, Faculty of Agriculture , Kafr Alcheikh University, Egypt \\ Correspondence: Gaber Mohamed M. Abdel Gawad, Associate Professor of Economics Seconded From \\ Economics and Foreign Trade Department, Faculty of Commerce and Business Administration, Helwan \\ University; Egypt to College of Business Administration in Hotat Bani Tamim, Salman Bin Abdulaziz University, \\ P.O. Box, 13 Hotat Bani Tamim 11941, Kingdom of Saudi Arabia. E-mail: gabergagm@yahoo.com
}

Received: December 31, 2013

Accepted: January 28, 2014

Online Published: March 25, 2014

doi:10.5539/ijef.v6n4p79

URL: http://dx.doi.org/10.5539/ijef.v6n4p79

\begin{abstract}
The study focus on testing the determinants of competitive advantage of dates marketing from Saudi Arabia through multi- regression model based on Porter's diamond, which is determined the factor that affecting on competitiveness of nations in international marketing, such as factor conditions, demand conditions, related and supporting industries, and company strategy; structure; and rivalry. Our study selected the most competitive countries for Saudi Arabia in marketing dates in its markets (like Egypt, Iraq, and Tunisia). The results of study showed that the four determinants are significant and $\mathrm{R}$ square is high more than $95 \%$ in all equations this is agree with our assumptions, but the signs parameters of these determinants are different from our expectations specially with the quantity of production in Saudi Arabia which appear negative with the value of export of dates from KSA, that is because the consumption of dates in domestic market is high and it absorbs the high quality kind of dates, which is needed for external market. We tested also the same determinants for the competitive countries (Egypt, Iraq, and Tunisia); we found the same results, except Egypt, which have huge domestic demand that is effect on demand conditions in this country. Our study suggested more studies are needed for related and supporting industries of dates with this crop, to save data base in this field, and give more attention for quality of dates, packaging and prices for Saudi exporting of dates.
\end{abstract}

Keywords: competitive advantage, dates marketing, Saudi Arabia

\section{Introduction}

Saudi Arabia is blessed with vast production of dates and have potential to contribute to export earning to a large extend .The date has an important place in the structure of Saudi Economy on both national level generally and on the level of agricultural sector particularly because of its active contribution in the economic activity, increasing the Saudi exports and fulfilling the needs of local market. The Kingdom of Saudi Arabia is at the forefront of the countries which produce and export the date at the same time and in the tradition of today's international trade, The Kingdom has many comparative and competitive advantages in both production and export process. In spite of advantages Saudi dates are not getting due recognition despite their superior quality, their presence in the global market is very limited and not all right to their volume of production.

\subsection{Research Objectives}

To study the production and marketing dates in local market, and study the general trends form dates exporting to the world markets, with analysis the geographic distribution of dates exporting in the world market and determinants of competitive advantage in the world market, and determine the determinants of competitive advantage of dates according to Porter approach and Vallroth approach, and it aims to estimate the parameters of competitive advantage determinants for exporting dates from Saudi Arabia and its competitive position with competitors in rest of the world.

\subsection{The Research Problem}

KSA is enjoying many natural resources but production and marketing both internally and externally dates do not commensurate with their potential and capabilities to take position in the world market in terms of 
competitive pricing, production and efficiency. This is the thing which indicates to existence of a problem faced by production and export sectors for the marketing of dates internally and externally.

\subsection{The Current Study}

Aims at knowing the current situation of dates production in KSA which effect in local and world market. Consequently problems faced by producers and marketers in the Kingdom. Also, it aims to study the existing marketing situation in order to know the different aspects related to production and marketing internally and externally with competitive advantages.

\section{Method}

The Study relies on many researches descriptive and quantitative methods such as regression analysis, rates of economic growth, and coefficients of commodity concentration as well as indicators of market share based on secondary data which will be collected from its different local and international resources depending upon the availability of data. It is expected that the study will show very important results which will have its economic return. Also, it will help to create a database which will be useful for decision makers in taking appropriate decisions with respect to production and marketing of dates internally and externally from the kingdom.

With this introduction, the paper is organized as follows. Section two presents a review of literature pertaining to determinants of the competitive advantage of marketing dates internally and externally and the choice of variables. Section three indicates the research methodology including data collection and model specification, and list of variables. Section four presents results and discussion. Section five concludes by pointing to a future research direction.

\section{Literature Review}

Abdoulhadi (2011) examines the study to assess the fruit characteristics to standardize quality norms in date cultivars of Saudi Arabia and he also studied four texture parameters viz, hardness, springiness, cohesiveness and resilience of Khalas, Sheshi and Reziz date cultivars. From the finding of this investigation will strengthen the data base of fruit quality norms in major Saudi Arabian date cultivars and boost export of dates from the Kingdom, besides protecting the identity of the cultivars studied.

Kahtani (2007) examines the study the expected demand of dates will increase when the population increases. Study estimated the production of dates has increased in the last five years and opened avenues for domestic and foreign marketing channels. Study focused the comparison between specific outlets and varieties of dates in Riyadh region. Variance analysis revealed the study about prices and varieties of dates except AlSukkari but significant differences in marketing margin of dates such as AlHulawa, AlSukkari and AlSufari only.

Liu (2003) analysed the study of marketing potentials of date palm fruits in the European market including non-traditional dates in the EU markets. The study found that there was room for increased imports of deglet nour dates (or other varieties with similar taste and texture) provided high standards of quality (including low infestation rate), packaging and traceability could be met. Prices were not expected to increase substantially from their present level. Mejool has attracted major interest in the UK and France and fetched high prices. It appeared to have good market prospects but some logistical constraints due to the low supply volume and retailer hesitations still needed to be solved. Conversely, the potential for hayani and bahri seemed limited to a small ethnic market.

Marshudi (2002) conducted the study of Oman traditional date palms with reference to production and improvement of date palms in Oman. This study presented date palm crop in terms of its traditional practice and economic development in Oman. The results showed that the quality of dates produced has not yet met approved standards and, therefore, the return to producers is not maximized.

Mehmoudi (2008) examined the enhancement of date palm processing marketing through organic culture. He found that some challenges have been paid for production of dates. Date usually all over the world with a high value confectionery, but still a fresh fruit remain an important subsistence crop in most of the desert areas.

Mikki (1998) Conducted the study on the present status and future prospects of dates and dates palm industries in Saudi Arabia and highlighted the present status of the-dates business in terms of industry structure and its attractiveness. The study finally illustrated the importance of cooperation and coordination of the existing date processing plants with research centres and universities involved in conducting research on various aspects of dates processing and date palm residues.

Rashidi (2013) explored the study the motivation to export perceived by small and medium sized business considering within KSA. He examined and perceived export motivations differences and influence of such 
motivations on export related decision within manufacturing settings. In the findings of the study shows that KSA SMEs motivated more by external exporting motivations and the lower risk perceived and higher commitment to export resulted.

Shreed, Jamel and Abbed (2012) conducted the study and calculated the average price of dates for each of the groups of importing and exporting countries and found in there and study the status of Saudi Arabian dates in the global markets and their suitability for exports. Five potential strengths of Saudi Arabian dates were identified that may be used either individually or collectively to strengthen the exports of dates from the Kingdom in each of the five date importing groups of countries where we also determined the potential market opportunities.

Aljanobi (2009) analysed in the study the date industry still limited mainly in cleaning and packing with a few new products or by-products. The goal of this project was to evaluate the current date factories, improve and develop the date industry in the areas of adding value to date processing new products and by-products from low quality or wasted date. It is possible only when by evaluating the current local date factories in the areas of economical, administrational and technical aspects and by applying and developing selected conversion operations such as extrusion and fermentation to utilize low grade and wasted. The challenge ahead for any researcher in the product and/or process development area is to produce unique, innovative products based on current feasible market demands and availability of enormous amounts of raw materials.

Khushk (2009) conducted the study about date producing and consuming areas of the Sindh city. Efforts were made to describe and analyse the structure and operations of date marketing channels and quantify marketing margins of producers and other market agencies. Survey results showed that eighty percent of date producers sold the harvesting rights of date orchard to pre-harvest contractors. The producer's share in retail price was estimated on per forty $\mathrm{kg}$ basis. The results revealed that maximum share of producer were thirty seven percent in fresh dates and twenty four percent in hydrated dates.

Mahmoudi (2008) examined the organic farming is being promoted as an environmentally-friendly approach in most developed countries, there has been little consideration for developing countries, which are the main producers of dates. This article examined the potential benefits, and processing, marketing and pest control challenges, associated with organic date palm production.

\section{Determinants of Competitive Advantage}

According Porter approach the Determinants of competitive advantage of nation are factor conditions, demand conditions, related and support industries, and company strategy, structure and rivalry. He also proposes two other factors, namely government policy and chance (exogenous shocks) this is called porter s diamond. Porter approach looks at cluster in which a number of small industries. But we develop this approach to explain how we can use this diamond in explaining the determinants of the competitive advantage of exporting date from Saudi Arabia, we will introduce some discussions about this diamond.

\subsection{Factor Conditions}

All classical trade theories take land, labour, and capital as factors of production; put Porter (1990a) distinguishes between the following categories: human resources, physical resources, knowledge resources, capital resources and infrastructure. Factor conditions are further subdivided into basic and advanced factors that can be either general or specialised. Basic factors such as unskilled labour, raw materials, climatic conditions and water resources are inherited and require little or no new investment to be utilised in the production process. Advanced factors are created and upgraded through reinvestment and innovation to specialised factors, which according to Porter form the basis for the sustainable competitive advantage of a country.

Porter analysed the competitive advantage of nation and applied his theory on same industries and sectors like tourism, but with date exports as agricultural product, we will depend on natural resources like land, weather, and water, which need for palm tree, with unskilled labour. These factors already exist in Saudi Arabia. So we will take Saudi area harvest and Saudi production of dates as quantitative variables of factor conditions.

\subsection{Demand Conditions}

In the local market can help companies create a competitive advantage, when sophisticated home market buyers pressure firms to innovate faster and to create more advanced products than those of competitors, but in the world market the demand conditions can be expressed in the form of a quantitative world imports of dates.

\subsection{Related and Supporting Industry}

It can produce inputs which are important for innovation and internationalization. These industries provide cost-effective inputs, but they also participate in the upgrading process, thus stimulating other companies in the 
chain to innovate. But in our study we use related and supported industries such as:

-Dates Packaging Industry (Packaging companies and individual packaging);

-Dates Processing Industry;

-Logistics Industry;

-Cellulosic Industries of the Date Palm: for handicraft, organic fertilizers and fermentation industries from date palm residues.

\subsection{Company Strategy, Structure, and Rivalry}

It constitutes the fourth determinant of competitiveness. The way in which companies are created, set goals and are managed is important for success. But the presence of intense rivalry in the home base is also important; it creates pressure to innovate in order to upgrade competitiveness. But in this study we use competitive countries as a proxy variable for this element applying on export of dates from Egypt, Iraq, and Tunisia, these three countries are the main competitor for dates export from Saudi Arabia.

We will exclude the impact of the government and the chance of a quantitative model to be applied. As a theoretical assumption for the model, and the Period of study from 1991 to 2011 in Saudi Arabia,

\section{Model Formulation}

Dates exports from Saudi $=\mathrm{f}\{$ Factor Condition (production + Harvest area) + Demand Condition (world imports) + Related and Supporting Industries (dates industries) + Company Strategy, Structure, and Rivalry (export of competitive countries like Egypt, Iraq, and Tunisia)\}

$$
\begin{gathered}
D X_{j}=f\left(F C_{j}+D C_{w}+R I_{j}+C S_{k}\right) \\
F C_{j}=f\left(A H_{j}+Q P_{j}\right) \\
C S_{k}=f\left(V X_{E}+V X_{I}+V X_{T}\right)
\end{gathered}
$$

We can formulate the model in econometric form as follow:

$$
\begin{gathered}
D X_{S}=\alpha_{0 S}+\beta_{I S} A H_{S}+\beta_{2 S} Q P_{S}+\beta_{3 S} D C_{w}+\beta_{4 S} R I_{S}+\beta_{5 S} V X_{E}+\beta_{6 S} V X_{I}+\beta_{7 S} V X_{T}+\varepsilon \\
D X_{E}=\alpha_{0 E}+\beta_{I E} A H_{E}+\beta_{2 E} Q P_{E}+\beta_{3 E} D C_{w}+\beta_{4 E} R I_{E}+\beta_{5 E} V X_{S}+\beta_{6 E} V X_{I}+\beta_{7 E} V X_{T}+\varepsilon \\
D X_{I}=\alpha_{0 I}+\beta_{I I} A H_{I}+\beta_{2 I} Q P_{I}+\beta_{3 I} D C_{w}+\beta_{4 I} R I_{S}+\beta_{5 I} V X_{E}+\beta_{6 I} V X_{S}+\beta_{7 I} V X_{T}+\varepsilon \\
D X_{T}=\alpha_{0 T}+\beta_{I T} A H_{T}+\beta_{2 T} Q P_{T}+\beta_{3 T} D C_{w}+\beta_{4 T} R I_{T}+\beta_{5 T} V X_{E}+\beta_{6 T} V X_{I}+\beta_{7 T} V X_{T}+\varepsilon
\end{gathered}
$$

Where:

$D X_{j}=$ Dates Exports from Country $\mathrm{j}$ (Value of Country $\mathrm{j}$ Exports of dates);

$F C_{j}=$ Factors Conditions in Country $\mathrm{j}$;

$A H_{S}=$ Area Harvested in Saudi;

$A H_{E}=$ Area Harvested in Egypt;

$A H_{I}=$ Area Harvested in Iraq;

$A H_{T}=$ Area Harvested in Tunisia;

$Q P_{S}=$ Quantity of Production in Saudi;

$Q P_{E}=$ Quantity of Production in Egypt;

$Q P_{I}=$ Quantity of Production in Iraq;

$Q P_{T}=$ Quantity of Production in Tunisia;

$D C_{w}=$ Demand Conditions (Value of World Imports of Dates);

$R I_{S}=$ Related Industries in Saudi \{we will use Quantity of Saudi Exports (tons) as a proxy variable to measure $\mathrm{RI}\}$;

$R I_{E}=$ Related Industries in Egypt (we will use Quantity of Egypt Exports (tons) as a proxy variable to measure $\mathrm{RI}$;

$R I_{I}=$ Related Industries in Iraq \{we will use Quantity of Iraq Exports (tons) as a proxy variable to measure RI\};

$R I_{T}=$ Related Industries in Tunisia \{we will use Quantity of Tunisia Exports (tons) as a proxy variable to measure RI\}; 
$C S_{k}=$ Company Strategy, Structural, and Rivalry (Competitive Countries k);

$V X_{E}=$ Value of Exports from Egypt;

$V X_{S}=$ Value of Exports from Saudi;

$V X_{I}=$ Value of Exports from Iraq;

$V X_{T}=$ Value of Exports from Tunisia;

$\alpha_{0}$ Is intercept for the country $\mathrm{j}$ in the equations (4), (5), (6), and (7?);

$\beta_{1, \ldots, 7}$ Are parameters of independent variables for the country $\mathrm{j}$ in the equations (4), (5), (6), and (7?);

$\varepsilon$ Is random variable or error term for the country $\mathrm{j}$ in the equations (4), (5), (6), and (7?).

\section{Data and Variables}

We collected data depending on database of FAO, which available on FAOSTAT website, in Tables 1, 2, 3 and 4, and processing it's on SPSS to make regressions for equations (4), (5), (6), and (7) to estimate parameters of the equations and determine R Square, T test, and Significant of estimation for Saudi Arabia and three competitive countries (Egypt, Iraq, and Tunisia).

To test the main four variables for Porter's Diamond \{Factors Conditions (FC), Demand Conditions (DC), Related and Supporting Industries (RI), and Company Strategy, Structure, and Rivalry (CS) $\}$, we use available quantitative data about Area Harvested (AH) and Quantity of Production (QP) to measure (FC), and use world imports of dates to measure (DC), but we did not find data about related and supporting industries(RI) so we take quantity of export as a proxy variable to measure this factor where all exports allows include industrial dates ( like packaging dates, and dates processing industry), and we use alue of Dates Exports(VX) from competitive countries ( like Egypt, Iraq, and Tunisia) in case of Saudi, and change Saudi with three countries in case of every country of them respectively, as a proxy variable to measure Country Strategy and Rivalry (CS).

The previse four variables used as independent variables, and Value of Dates Exports (DX) used as dependent variables for Saudi Arabia, and the three competitive countries in four equations (4), (5), (6), and (7) respectively.

\section{Results}

From Table 5 the results of estimation show all equations are significant and R square high more than $95 \%$, that is means all changes in dependent variables are explain by independent variables, these results agree with $\mathrm{F}$ value and T test, but signs of parameters give us different explanations than we assume, especially $\left(\beta_{3}\right)$ in case of Egypt and Iraq, where we assume Demand Conditions (DC) have a positive relationship with value of export (DX) as Porter assumed, this may be explain in case of Egypt by huge size of domestic demand compared with world demand on Egyptian dates and in Iraq quality of dates are different from quality of dates in both Saudi and Tunisia.

In Tunisia the signs of $\left(\beta_{1}\right.$ and $\left.\beta_{2}\right)$ are also negative, that is because Area Harvested (AH) Quantity of Production $(\mathrm{QP})$ of dates are small compared with other countries, and relative weight of Tunisia's exports. The sings of $\left(\beta_{5}\right.$, $\beta_{6}$, and $\beta_{7}$ ) with Egypt in equation (5), Iraq in equation (6), and Tunisia in equations (7), and (4) respectively are also negative, that is agree with our assumption, where exports from these countries are compete with exports from Saudi Arabia in the world market of dates. The Kingdom enjoys many natural resources with production both internally and externally with their potential and capabilities to take position in the world market with reference to Egypt, Iraq and Tunisia in terms of competitive pricing, production and efficiency with the competitive advantages. In our study we determined Porter comprises factor conditions, demand conditions, related and supported industries was formulated the model in econometric form. In Egypt, date production was produced in large quantity but it was little progress in mid-nineties while value of exports was increased in large quantity. Demand condition and value of exports were found impressive due to market demand. In Iraq demand conditions have positive relationship with value of export while qualities of dates are quite different compare with both Saudi and Tunisia. In Tunisia area harvested with quality of production of dates are less progressive with other countries, finally our study emphasises to determine competitive advantages for the dates marketing in terms of quantity of exports and imports with the selected countries as discussed above with the neighbouring countries. Though these countries have enough potentials to compete largely exporting of dates from Saudi Arabia in the world market with regard to marketing of dates in the world market from the Kingdom. 
Table 1. Kingdom of Saud Arabia: data of dates production and trade through period (from 1990 to 2011) for equation (4)

\begin{tabular}{|c|c|c|c|c|c|c|c|c|}
\hline Year & $\begin{array}{l}\text { Saudi Area } \\
\text { Harvested } \\
\mathrm{Ha} \\
\left(A H_{s}\right)\end{array}$ & $\begin{array}{l}\text { Saudi } \\
\text { Production } \\
\text { (tons) } Q P_{s}\end{array}$ & $\begin{array}{l}\text { Quantity of } \\
\text { Saudi } \\
\text { Exports } \\
\text { (tons) } R I_{s}\end{array}$ & $\begin{array}{l}\text { Value of } \\
\text { Saudi Exports } \\
(\$ 1000) D X_{s}\end{array}$ & $\begin{array}{l}\text { Value of } \\
\text { World } \\
\text { Imports } \\
(\$ 1000) \\
D C_{w} \\
\end{array}$ & $\begin{array}{l}\text { Value of } \\
\text { Egypt } \\
\text { Exports } \\
(\$ 1000) \\
V X_{E} \\
\end{array}$ & $\begin{array}{l}\text { Value of } \\
\text { Iraq } \\
\text { Exports } \\
(\$ 1000) \\
V X_{I} \\
\end{array}$ & $\begin{array}{l}\text { Value of } \\
\text { Tunisia } \\
\text { Exports } \\
(\$ 1000) \\
V X_{T} \\
\end{array}$ \\
\hline 1990 & 72379 & 527881 & 20299 & 13959 & 244743 & 904 & 37000 & 51131 \\
\hline 1991 & 75757 & 528074 & 18272 & 10671 & 228242 & 1511 & 5500 & 52928 \\
\hline 1992 & 79575 & 552493 & 18428 & 14876 & 265302 & 1606 & 6500 & 49380 \\
\hline 1993 & 83703 & 563008 & 18181 & 25223 & 275159 & 2473 & 2200 & 47531 \\
\hline 1994 & 85790 & 567762 & 16622 & 13604 & 300872 & 2662 & 6000 & 56218 \\
\hline 1995 & 93825 & 589261 & 34323 & 21785 & 279028 & 1061 & 6000 & 61663 \\
\hline 1996 & 100858 & 616908 & 30846 & 21095 & 304985 & 784 & 8500 & 47914 \\
\hline 1997 & 106137 & 649239 & 25310 & 21133 & 281298 & 1277 & 16000 & 47099 \\
\hline 1998 & 106460 & 648000 & 24852 & 19073 & 289234 & 487 & 20000 & 61457 \\
\hline 1999 & 141750 & 712000 & 7100 & 5300 & 270503 & 1958 & 5000 & 47175 \\
\hline 2000 & 142450 & 734844 & 28248 & 18320 & 265941 & 1767 & 6000 & 38590 \\
\hline 2001 & 139099 & 817887 & 31881 & 18694 & 270730 & 600 & 1400 & 73412 \\
\hline 2002 & 139979 & 829540 & 33925 & 24248 & 273424 & 2115 & 2000 & 68621 \\
\hline 2003 & 141421 & 884088 & 34875 & 24585 & 309038 & 633 & 993 & 73921 \\
\hline 2004 & 148801 & 941293 & 47535 & 31739 & 368771 & 1370 & 4392 & 84382 \\
\hline 2005 & 150744 & 970488 & 51098 & 32456 & 425675 & 2463 & 20085 & 100771 \\
\hline 2006 & 152402 & 977036 & 44087 & 36183 & 492652 & 3153 & 9136 & 91563 \\
\hline 2007 & 155734 & 982546 & 48762 & 40529 & 591340 & 3014 & 9532 & 164759 \\
\hline 2008 & 157074 & 986409 & 50891 & 56514 & 663066 & 7301 & 59484 & 170388 \\
\hline 2009 & 161975 & 991660 & 1593 & 1650 & 691528 & 17535 & 46886 & 176280 \\
\hline 2010 & 171975 & 1089350 & 73362 & 78126 & 733340 & 18529 & 35913 & 200091 \\
\hline 2011 & 172297 & 1122820 & 77795 & 86293 & 796501 & 28211 & 46851 & 211451 \\
\hline
\end{tabular}

Source: FAOSTAT | C FAO Statistics Division 2013. 23 September 2013. http://faostat3.fao.org/faostat-gateway/go/to/download/Q/QC/E.

Table 2. Egypt: data of dates production and trade through period (from 1990 to 2011) for equation (5)

\begin{tabular}{|c|c|c|c|c|c|c|c|c|}
\hline Year & $\begin{array}{l}\text { Egypt } \\
\text { Area } \\
\text { Harvested } \\
\mathrm{Ha} \\
\left(A H_{E}\right) \\
\end{array}$ & $\begin{array}{l}\text { Egypt } \\
\text { Production } \\
\text { (tons) } Q P_{E}\end{array}$ & $\begin{array}{l}\text { Quantity of } \\
\text { Egypt } \\
\text { Exports (tons) } \\
R I_{E}\end{array}$ & $\begin{array}{l}\text { Value of } \\
\text { Egypt } \\
\text { Exports } \\
(\$ 1000) \\
D X_{E} \\
\end{array}$ & $\begin{array}{l}\text { Value of } \\
\text { World } \\
\text { Imports } \\
(\$ 1000) \\
D C_{w} \\
\end{array}$ & $\begin{array}{l}\text { Value of } \\
\text { Saudi } \\
\text { Exports } \\
(\$ 1000) \\
V X_{S} \\
\end{array}$ & $\begin{array}{l}\text { Value of } \\
\text { Iraq } \\
\text { Exports } \\
(\$ 1000) \\
V X_{I} \\
\end{array}$ & $\begin{array}{l}\text { Value of } \\
\text { Tunisia } \\
\text { Exports } \\
(\$ 1000) \\
V X_{T} \\
\end{array}$ \\
\hline 1990 & $21,816.00$ & $541,963.00$ & $1,686.00$ & 904 & 244743 & 13959 & 37000 & 51131 \\
\hline 1991 & $27,000.00$ & $603,490.00$ & $3,011.00$ & 1511 & 228242 & 10671 & 5500 & 52928 \\
\hline 1992 & $27,450.00$ & $603,652.00$ & $3,049.00$ & 1606 & 265302 & 14876 & 6500 & 49380 \\
\hline 1993 & $22,269.00$ & $631,290.00$ & $5,407.00$ & 2473 & 275159 & 25223 & 2200 & 47531 \\
\hline 1994 & $25,652.00$ & $646,039.00$ & $5,653.00$ & 2662 & 300872 & 13604 & 6000 & 56218 \\
\hline 1995 & $25,652.00$ & $677,934.00$ & $2,513.00$ & 1061 & 279028 & 21785 & 6000 & 61663 \\
\hline 1996 & $27,296.00$ & $738,147.00$ & $2,201.00$ & 784 & 304985 & 21095 & 8500 & 47914 \\
\hline 1997 & $28,000.00$ & $740,838.00$ & $1,916.00$ & 1277 & 281298 & 21133 & 16000 & 47099 \\
\hline 1998 & $29,000.00$ & $839,805.00$ & 674.00 & 487 & 289234 & 19073 & 20000 & 61457 \\
\hline 1999 & $28,195.00$ & $905,953.00$ & $3,588.00$ & 1958 & 270503 & 5300 & 5000 & 47175 \\
\hline 2000 & $28,982.00$ & $1,006,710.00$ & $2,669.00$ & 1767 & 265941 & 18320 & 6000 & 38590 \\
\hline 2001 & $29,461.00$ & $1,113,270.00$ & $1,190.00$ & 600 & 270730 & 18694 & 1400 & 73412 \\
\hline 2002 & $29,632.00$ & $1,090,004.00$ & $4,545.00$ & 2115 & 273424 & 24248 & 2000 & 68621 \\
\hline 2003 & $32,864.00$ & $1,121,890.00$ & $1,839.00$ & 633 & 309038 & 24585 & 993 & 73921 \\
\hline 2004 & $34,528.00$ & $1,166,182.00$ & $2,861.00$ & 1370 & 368771 & 31739 & 4392 & 84382 \\
\hline 2005 & $36,150.00$ & $1,159,690.00$ & $4,076.00$ & 2463 & 425675 & 32456 & 20085 & 100771 \\
\hline 2006 & $35,780.00$ & $1,328,720.00$ & $5,090.00$ & 3153 & 492652 & 36183 & 9136 & 91563 \\
\hline 2007 & $36,450.00$ & $1,313,696.00$ & $4,704.00$ & 3014 & 591340 & 40529 & 9532 & 164759 \\
\hline
\end{tabular}




\begin{tabular}{lllllllll}
\hline 2008 & $36,828.00$ & $1,326,133.00$ & $8,995.00$ & 7301 & 663066 & 56514 & 59484 & 170388 \\
2009 & $36,924.00$ & $1,270,478.00$ & $14,659.00$ & 17535 & 691528 & 1650 & 46886 & 176280 \\
2010 & $41,945.00$ & $1,352,954.00$ & $19,562.00$ & 18529 & 733340 & 78126 & 35913 & 200091 \\
2011 & $41,652.00$ & $1,373,570.00$ & $23,792.00$ & 28211 & 796501 & 86293 & 46851 & 211451 \\
\hline
\end{tabular}

Source: FAOSTAT | C FAO Statistics Division 2013 | 23 September 2013. http://faostat3.fao.org/faostat-gateway/go/to/download/Q/QC/E and http://faostat3.fao.org/faostat-gateway/go/to/download/T/TP/E.

Table 3. Iraq: data of dates production \& trade through period (from 1990 to 2011) for equation (6)

\begin{tabular}{|c|c|c|c|c|c|c|c|c|}
\hline Year & $\begin{array}{l}\text { Iraq } \\
\text { Area Harvested } \\
\mathrm{Ha} \\
\left(A H_{I}\right)\end{array}$ & $\begin{array}{l}\text { Iraq } \\
\text { Production } \\
\text { (tons) } \\
Q P_{I}\end{array}$ & $\begin{array}{l}\text { Quantity of Iraq } \\
\text { Exports (tons) } \\
R I_{I}\end{array}$ & $\begin{array}{l}\text { Value of } \\
\text { Iraq } \\
\text { Exports } \\
(\$ 1000) \\
D X_{I} \\
\end{array}$ & $\begin{array}{l}\text { Value of } \\
\text { World } \\
\text { Imports } \\
(\$ 1000) \\
D C_{w} \\
\end{array}$ & $\begin{array}{l}\text { Value of } \\
\text { Egypt } \\
\text { Exports } \\
(\$ 1000) \\
V X_{E} \\
\end{array}$ & $\begin{array}{l}\text { Value of } \\
\text { Saudi } \\
\text { Exports } \\
(\$ 1000) \\
V X_{S} \\
\end{array}$ & $\begin{array}{l}\text { Value of } \\
\text { Tunisia } \\
\text { Exports } \\
(\$ 1000 \\
V X_{T} \\
\end{array}$ \\
\hline 1990 & $123,510.00$ & $544,930.00$ & $190,000.00$ & 37000 & 244743 & 904 & 13959 & 51131 \\
\hline 1991 & $115,670.00$ & $566,220.00$ & $20,000.00$ & 5500 & 228242 & 1511 & 10671 & 52928 \\
\hline 1992 & $116,000.00$ & $447,840.00$ & $22,000.00$ & 6500 & 265302 & 1606 & 14876 & 49380 \\
\hline 1993 & $136,000.00$ & $612,580.00$ & $10,000.00$ & 2200 & 275159 & 2473 & 25223 & 47531 \\
\hline 1994 & $165,000.00$ & $675,820.00$ & $30,000.00$ & 6000 & 300872 & 2662 & 13604 & 56218 \\
\hline 1995 & $168,000.0$ & $881,020.00$ & $40,000.00$ & 6000 & 279028 & 1061 & 21785 & 61663 \\
\hline 1996 & $176,000.00$ & $797,450.00$ & $50,000.00$ & 8500 & 304985 & 784 & 21095 & 47914 \\
\hline 1997 & $156,000.00$ & $750,000.00$ & $90,000.00$ & 16000 & 281298 & 1277 & 21133 & 47099 \\
\hline 1998 & $144,000.00$ & $913,000.00$ & $100,000.00$ & 20000 & 289234 & 487 & 19073 & 61457 \\
\hline 1999 & $90,000.00$ & $764,000.00$ & $30,000.00$ & 5000 & 270503 & 1958 & 5300 & 47175 \\
\hline 2000 & $110,000.00$ & $932,000.00$ & $30,000.00$ & 6000 & 265941 & 1767 & 18320 & 38590 \\
\hline 2001 & $101,500.00$ & $907,000.00$ & $4,000.00$ & 1400 & 270730 & 600 & 18694 & 73412 \\
\hline 2002 & $101,500.00$ & $866,000.00$ & $8,000.00$ & 2000 & 273424 & 2115 & 24248 & 68621 \\
\hline 2003 & $101,500.00$ & $868,000.00$ & $5,016.00$ & 993 & 309038 & 633 & 24585 & 73921 \\
\hline 2004 & $89,053.00$ & $448,380.00$ & $23,485.00$ & 4392 & 368771 & 1370 & 31739 & 84382 \\
\hline 2005 & $50,000.00$ & $404,030.00$ & $146,995.00$ & 20085 & 425675 & 2463 & 32456 & 100771 \\
\hline 2006 & $101,500.00$ & $432,360.00$ & $42,358.00$ & 9136 & 492652 & 3153 & 36183 & 91563 \\
\hline 2007 & $105,000.00$ & $430,861.00$ & $37,063.00$ & 9532 & 591340 & 3014 & 40529 & 164759 \\
\hline 2008 & $101,500.00$ & $476,318.00$ & $264,640.00$ & 59484 & 663066 & 7301 & 56514 & 170388 \\
\hline 2009 & $110,000.00$ & $507,002.00$ & $183,701.00$ & 46886 & 691528 & 17535 & 1650 & 176280 \\
\hline 2010 & $123,000.00$ & $567,668.00$ & $120,123.00$ & 35913 & 733340 & 18529 & 78126 & 200091 \\
\hline 2011 & $123,230.00$ & $619,182.00$ & $138,437.00$ & 46851 & 796501 & 28211 & 86293 & 211451 \\
\hline
\end{tabular}

Source: FAOSTAT | C FAO Statistics Division 2013 | 23 September 2013. http://faostat3.fao.org/faostat-gateway/go/to/download/Q/QC/E and http://faostat3.fao.org/faostat-gateway/go/to/download/T/TP/E.

Table 4. Tunisia: data of dates production and trade through period (from 1990 to 2011) for equation (7)

\begin{tabular}{|c|c|c|c|c|c|c|c|c|}
\hline Year & $\begin{array}{l}\text { Tunisia Area } \\
\text { Harvested } \\
\mathrm{Ha} \\
\left(A H_{T}\right)\end{array}$ & $\begin{array}{l}\text { Tunisia } \\
\text { Production } \\
\text { (tons) } \\
Q P_{T}\end{array}$ & $\begin{array}{l}\text { Quantity of } \\
\text { Tunisia } \\
\text { Exports } \\
\text { (tons) } \\
R I_{T}\end{array}$ & $\begin{array}{l}\text { Value of } \\
\text { Tunisia } \\
\text { Exports } \\
(\$ 1000) \\
D X_{T}\end{array}$ & $\begin{array}{l}\text { Value of } \\
\text { World } \\
\text { Imports } \\
(\$ 1000) \\
D C_{w}\end{array}$ & $\begin{array}{l}\text { Value of } \\
\text { Egypt } \\
\text { Exports } \\
(\$ 1000) \\
V X_{E}\end{array}$ & $\begin{array}{l}\text { Value of } \\
\text { Iraq } \\
\text { Exports } \\
(\$ 1000) \\
V X_{I}\end{array}$ & $\begin{array}{l}\text { Value of } \\
\text { Saudi } \\
\text { Exports } \\
(\$ 1000 \\
V X_{S} \\
\end{array}$ \\
\hline 1990 & $21,000.00$ & $81,200.00$ & $18,031.00$ & 51131 & 244743 & 904 & 37000 & 13959 \\
\hline 1991 & $22,000.00$ & $75,000.00$ & $19,453.00$ & 52928 & 228242 & 1511 & 5500 & 10671 \\
\hline 1992 & $22,400.00$ & $75,500.00$ & $17,120.00$ & 49380 & 265302 & 1606 & 6500 & 14876 \\
\hline 1993 & $26,150.00$ & $86,000.00$ & $18,510.0$ & 47531 & 275159 & 2473 & 2200 & 25223 \\
\hline 1994 & $28,000.00$ & $74,000.00$ & $20,781.00$ & 56218 & 300872 & 2662 & 6000 & 13604 \\
\hline 1995 & $29,460.00$ & $69,000.00$ & $20,872.00$ & 61663 & 279028 & 1061 & 6000 & 21785 \\
\hline 1996 & $29,480.00$ & $74,000.00$ & $18,216.00$ & 47914 & 304985 & 784 & 8500 & 21095 \\
\hline 1997 & $27,000.00$ & $95,000.00$ & $21,310.00$ & 47099 & 281298 & 1277 & 16000 & 21133 \\
\hline 1998 & $30,000.00$ & $103,000.00$ & $27,299.00$ & 61457 & 289234 & 487 & 20000 & 19073 \\
\hline 1999 & $31,000.00$ & $103,000.00$ & $23,099.00$ & 47175 & 270503 & 1958 & 5000 & 5300 \\
\hline
\end{tabular}




\begin{tabular}{|c|c|c|c|c|c|c|c|c|}
\hline 2000 & $31,610.00$ & $105,000.0$ & $22,411.00$ & 38590 & 265941 & 1767 & 6000 & 18320 \\
\hline 2001 & $39,980.00$ & $112,620.00$ & $47,043.00$ & 73412 & 270730 & 600 & 1400 & 18694 \\
\hline 2002 & $40,000.00$ & $120,810.00$ & $41,890.00$ & 68621 & 273424 & 2115 & 2000 & 24248 \\
\hline 2003 & $40,000.00$ & $116,970.00$ & $37,079.00$ & 73921 & 309038 & 633 & 993 & 24585 \\
\hline 2004 & $40,000.00$ & $122,000.00$ & $40,432.00$ & 84382 & 368771 & 1370 & 4392 & 31739 \\
\hline 2005 & $39,970.00$ & $113,000.00$ & $50,163.00$ & 100771 & 425675 & 2463 & 20085 & 32456 \\
\hline 2006 & $40,740.00$ & $125,000.00$ & $42,764.00$ & 91563 & 492652 & 3153 & 9136 & 36183 \\
\hline 2007 & $39,830.00$ & $124,000.00$ & $68,856.00$ & 164759 & 591340 & 3014 & 9532 & 40529 \\
\hline 2008 & $39,300.00$ & $145,000.00$ & $69,485.00$ & 170388 & 663066 & 7301 & 59484 & 56514 \\
\hline 2009 & $45,900.00$ & $162,000.00$ & $77,254.00$ & 176280 & 691528 & 17535 & 46886 & 1650 \\
\hline 2010 & $49,300.00$ & $174,000.00$ & $84,282.00$ & 200091 & 733340 & 18529 & 35913 & 78126 \\
\hline 2011 & $51,000.00$ & $180,000.00$ & $86,910.00$ & 211451 & 796501 & 28211 & 46851 & 86293 \\
\hline
\end{tabular}

Source: FAOSTAT | C FAO Statistics Division 2013 | 23 September 2013. http://faostat3.fao.org/faostat-gateway/go/to/download/Q/QC/E and http://faostat3.fao.org/faostat-gateway/go/to/download/T/TP/E.

Table 5. Result of estimation the effects of determinants of the competitive advantage on dates exports

\begin{tabular}{|c|c|c|c|c|c|c|c|c|c|c|c|c|c|}
\hline \multirow{2}{*}{$\begin{array}{l}\text { Country } \\
\text { j }\end{array}$} & \multicolumn{13}{|c|}{$D X_{j}=\alpha_{0 j}+\beta_{1 j} A H_{j}+\beta_{2 j} Q P_{j}+\beta_{3 j} D C_{w}+\beta_{4 j} R I_{j}+\beta_{5 j} V X_{E}+\beta_{6 j} V X_{I}+\beta_{7 j} V X_{T}+\varepsilon$} \\
\hline & $\alpha_{0}$ & $\beta_{1}$ & $\beta_{2}$ & $\beta_{3}$ & $\beta_{4}$ & $\beta_{5}$ & $\beta_{6}$ & $\beta_{7}$ & $\begin{array}{c}\mathrm{R} \\
\text { Square }\end{array}$ & F Value & $\mathrm{T}$ Test & Sig. & $\begin{array}{l}\text { Eq. } \\
\text { No. }\end{array}$ \\
\hline Saudi & 3691.63 & 0.109 & -0.052 & 0,048 & 0.998 & 0.488 & 0.017 & -0.040 & 0.959 & 46.967 & 0,516 & .000 & (4) \\
\hline Egypt & -4509.9 & 0.161 & 6.337 & -0.008 & 1.230 & -0.034 & 0,045 & 0,006 & 0.976 & 82.725 & -1.427 & .000 & (5) \\
\hline Iraq & -5020.3 & 0.030 & 0.000 & -0.011 & 0.191 & 0.659 & -0.003 & 0,055 & 0.985 & 127.51 & -.1 .014 & .000 & (6) \\
\hline Tunisia & 29577.4 & -1.184 & -0.266 & 0.121 & 1.971 & 0.508 & -0.026 & 0.124 & 0.994 & 328.572 & 2.930 & .000 & (7) \\
\hline
\end{tabular}

Source: Estimated by SPSS package depending on data in previous tables from (1) to (4).

\section{Discussion}

Saudi Arabia is one of the top ten producing dates countries in the world, and among the exporting countries of dates (Egypt, Iraq, and Tunisia). The kingdom produces high quality premium dates that could potentially exported between time periods from 1990 to 2011, while these three countries are the main competitors for dates export from Saudi Arabia. The Kingdom of Saudi Arabia has vast production of dates and enough potential to contribute to export earning to a large extend especially with the neighboring countries, the dates has an important place in the structure of Saudi Economy of competitive advantages for the marketing of dates internally and externally from Saudi Arabia. Indeed the country is at the forefront with the countries Egypt, Iraq and Tunisia which produce and export the date at the same time and in the tradition of today's international trade. Porter diamond model used to test the variables factors conditions, demand conditions, related industries. While we assumed that Value of Dates Exports from competitive countries (like Egypt, Iraq, and Tunisia) in case of Saudi, as a proxy variable to measure Country Strategy and Rivalry. The study used quantitative data about area harvested and quantity production to measure factors conditions in Saudi Arabia and use world imports of dates to measure demand conditions. The estimated result was assumed demand conditions have a positive relationship with value of export as Porter assumed, this may clear that in case of Egypt by huge size of domestic demand compared with world demand on Egyptian dates and in Iraq quality of dates are different from quality of dates in both Saudi and Tunisia. Further study is needed to determine and to laid special emphasis for further investigation on determinants of competitive advantages for marketing with related and supporting industries for packaging and processing and logistics industries. This investigation will strengthen the data base for compete with Egypt, Iraq and Tunisia, marketing aspects and will support by the government of Saudi Arabia for facilitating proper market for dates growers and exporters. There is an urgent need to develop an export strategy for Saudi dates that would assure to compete in the world markets and increase sales of surplus dates from the Kingdom with proper marketing strategy in order to know related aspects of assured quality of production and marketing of dates from Saudi Arabia.

\section{Acknowledgements}

Researchers go all thanks to the Deanship of Scientific Research at Salman bin Abdul Aziz University for providing technical and financial support to facilitate the task of the researchers in the completion of this research, which is taken from project No. 181/A/33. 


\section{References}

Abdoulhadi et al. (2011). Assessing fruit characteristics to standardize quality norms in date cultivars of Saudi Arabia. Indian Journal of Science and Technology, 4(10).

Al Shreed et al. (2012). A study on the export of Saudi Arabian dates in the global markets. Journal of Development and Agricultural Economics, 4(9), 268-274. http://dx.doi.org/ 10.5897/JDAE12.068

Aljanobi et al. (2009). Evaluation and development of date industry in Saudi Arabia by using extrusion and fermentation techniques: Technical, managerial and economic studies. Funded project by King Abdul Aziz City for Science and Technology. A. T. 21-35.

Anonymous. (2006). The famous date varieties in the Kingdom of Saudi Arabia. Ed. Ministry of Agriculture, Kingdom of Saudi Arabia and Food and Agriculture Organization of the United Nations.

Dates Marketing Strategy. (2008). Pakistan horticulture development \& export board.

FAO. (2006). Date palm products. Retrieved from http://www.fao.org/docrep/t0681E/t0681e12.htm

Kahtani. (2007). Economic analysis of world demand for dates export in Saudi Arabia. Study by faculty member of College of Food Science and Agriculture, King Saud University.

Khushk et al. (2009). Marketing channels and margins of dates in Sindh, Pakistan. Journal of Agriculture Research, 47(3), 224-227.

Liu, P. (2002). The marketing potential of date palm fruits in the European market. Retrieved from $\mathrm{http}: / / w w w . f a o . o r g / E S / E S C / e n / 41470 / 41522 /$ highlight_102777en.html

Liu, P. (2003). The marketing potential of date palm fruits in the European market. FAO commodity and trade policy research working paper.

Mahmoudi et al. (2008). Enhancing date palm processing, marketing and pest control through organic culture. Journal of Organic Systems, 3(2).

Marshudi. (2002). Oman traditional date palms: Production and improvement of date palms in oman. Tropicultura, 20(4).

Mikki, M. (1998). Present status and future prospects of dates and dates palm industries in Saudi Arabia Proceedings. The first international conference on dates pal Al-In ,UAE March 8-10,1998.

Porter, M. E. (1990). The competitive advantage of nations. Harvard Business Review. Retrieved from http://kkozak.wz.cz/Porter.pdf

Rashidi, Y. A. (2013). Exporting motivations and saudi SMEs: An exploratory study. Proceedings of 8th Asian Business Research Conference 1-2 April 2013, Bangkok, Thailand.

Shuaidi, A. (2011). The eco metrics of investment in dates production in Saudi Arabia. The International Journal of Applied Economics and Finance, 5(3), 177-184. http://dx.doi.org/ 10.3923/IJAEF.2011.177.184

Smit, A. J. (2010). The competitive advantage of nations: Is porter's diamond framework a new theory that explains the international competitiveness of countries? Southern African Business Review, 14(1), 21-34.

Wikipedia. (2006). Date palm. Retrieved from http://en.wikipedia.org/wiki/Date_palm

\section{Copyrights}

Copyright for this article is retained by the author(s), with first publication rights granted to the journal.

This is an open-access article distributed under the terms and conditions of the Creative Commons Attribution license (http://creativecommons.org/licenses/by/3.0/). 